\title{
Biochar and its adsorbent power. How are scientific publications about this issue?
}

\author{
Biochar e seu poder adsorvente. Como estão as publicações científicas sobre esse assunto? \\ Biochar y su poder adsorbente. ¿Cómo están las publicaciones científicas sobre este tema?
}

Received: 07/21/2021 | Reviewed: 07/26/2021 | Accept: 07/29/2021 | Published: 08/05/2021

Priscilla Dors

ORCID: https://orcid.org/ 0000-0003-1672-6327 University the State of Santa Catarina, Brazil E-mail: priscilladors@gmail.com

Mari Lucia Campos

ORCID: https://orcid.org/ 0000-0003-3250-2067 University the State of Santa Catarina, Brazil E-mail: Mari.campos@udesc.br

Martha Andreia Brand

ORCID: https://orcid.org/ 0000-0001-5438-2081 University the State of Santa Catarina, Brazil E-mail: Martha.brand@udesc.br

David José Miquelluti

ORCID: https://orcid.org/ 0000-0002-7369-6163 University the State of Santa Catarina, Brazil E-mail: david.miquelluti@udesc.br

\begin{abstract}
Bibliometric analysis seeks to evaluate scientific productions, enabling the compilation of various types of information such as effective publications, authors and shows the direction of future productions. Biochar is the name given to biomass of plant origin that has undergone a burning process. The biochar has gained prominence in recent years for its versatile material. Rich in carbon and used for carbon sequestration, nutrient retention, it improves soil fertility, the physical and biological properties of the soil and increases agricultural yield. It is a promising adsorbent for the remediation of organic and inorganic contaminants from soil and water. This study aims to analyse qualitatively and quantitatively, using bibliometric methods, the publications of research articles related to the use of biochar as an adsorbent, in the period 2011-2021. The base data for this research were collected in October 2020, in the Scopus database. The selected articles were analysed with the aid of VOsviewer®. There was an advance in studies on biochar in the period. The largest number of articles cited and the highest productivity are Chinese. The predominant language is English and the predominant area is environmental sciences.
\end{abstract}

Keywords: Scopus; Bibliometric analysis; Biochar; Adsorption.

\section{Resumo}

A análise bibliométrica busca avaliar as produções cientificas, possibilitando a compilação de vários tipos de informações como publicações efetivas, autores e mostra o rumo de futuras produções. Biochar ou biocarvão é o nome dado a biomassa de origem vegetal que passou por um processo de queima. O biochar ganhou destaque nos últimos nos por seu um material versátil. Rico em carbono e usado para sequestro de carbono, retenção de nutrientes, melhora a fertilidade do solo, as propriedades físicas e biológicas do solo e aumento do rendimento agrícola. É adsorvente promissor para a remediação de contaminantes orgânicos e inorgânicos do solo e da água. Este estudo tem por objetivo analisar quali e quantitativamente, por meio de métodos bibliométricos, as publicações de artigos de pesquisa relacionadas ao uso do biochar como adsorvente de elementos traço, poluentes orgânicos e inorgânicos no período de 2011-2021. Os dados base para esta pesquisa foram coletados em outubro de 2020, na base de dados Scopus. Os artigos selecionados foram analisados com auxílio do VOsviewer®.Observou-se um avanço nos estudos sobre biochar no período. O maior número de artigos citados e a maior produtividade são chineses $\mathrm{O}$ idioma predominante é o inglês e a área predominante é a de ciências ambientais.

Palavras-chave: Scopus; Análise bibliométrica; Biochar; Adsorção.

\section{Resumen}

El análisis bibliométrico busca evaluar las producciones científicas, posibilitando la recopilación de diversos tipos de información como publicaciones efectivas, autores y espectáculos en la dirección de futuras producciones. Biochar es el nombre que se le da a la biomasa de la planta que ha sufrido un proceso de combustión. El biocarbón ha ganado protagonismo en los últimos años por su material versátil. Rico en carbono y utilizado para secuestro de carbono, retención de nutrientes, mejora la fertilidad del suelo, las propiedades físicas y biológicas del suelo y el rendimiento agrícola. Es un adsorbente prometedor para la remediación de contaminantes orgánicos e inorgánicos del suelo y el 
agua. Este estudio tiene como objetivo analizar cualitativa y cuantitativamente, utilizando métodos bibliométricos, las publicaciones de artículos de investigación relacionados con el uso de biocarbón como adsorbente, en el período 2011-2021. Los datos base para esta investigación se recopilaron en octubre de 2020, en la base de datos Scopus. Los artículos seleccionados fueron analizados con la ayuda de VOsviewer®. Hubo un avance en los estudios sobre biocarbón en el período. El mayor número de artículos citados y la mayor productividad son chinos. El idioma predominante es el inglés y el área predominante son las ciencias ambientales.

Palabras clave: Scopus; Análisis bibliométrico; Biocarbón; Adsorción.

\section{Introduction}

Biochar is a carbon-rich material produced by controlled pyrolysis with absence of oxygen, which allows the thermodegradation of biomass at temperatures ranging from $300^{\circ} \mathrm{C}$ to $900^{\circ} \mathrm{C}$ (Ajmal et al., 2020, Lehmann, 2007, Chen, 2014, Yu et al.,2017). Biochar can be produced from several sources, such as agricultural waste, wood waste, municipal waste (sewage sludge), etc. (Yu et al., 2017). Pyrolyzed material has gained prominence in the last decade for being a multifunctional component in the environment, which makes it a promising adsorbent for the remediation of organic and inorganic contaminants in soil and water. Because it has abundant active sites and high stability, it is widely used in agriculture and environmental protection Hassan et al., 2020, Wang et al., 2019a, Wang \& Wang 2018 ). It also promotes carbon sequestration in the soil, nutrient retention, improves soil fertility, the physical and biological properties of the soil and increased agricultural yield Satetinik et al.,2019, Arfaoui,2019, Albuquerque et al.,2013).

Biochar proprieties depends on the material chosen, as well as the pyrolysis temperature. The study of these conditions is important to obtain adsorbent materials that are effective and economically attractive (Junior, 2017).

Biochar studies began in 1870 when the "Terra Preto de Indio" was discovered (Lehmann e Joseph, 2009). Since then, the growing interest and expansion of the application of biochar has led to an increase in publications. Articles were published analysing the application of biochar. O'Connor et al. (2018) reviewed the remediation of soils contaminated by trace elements, Kavitha et al. (2018) researched the benefits and limitations of changing biochar in agricultural soils ( Li et al.,2020). Ahmed et al. (2018) carried out a global bibliometric analysis during the years 2000 to 2015, in order to investigate scientific publications on biochar research. Performing a search via Scopus using the word biochar, from 2012 to 202114,724 articles were found in several magazines and different areas related to the topic. There was an increase in the number of these publications in the years 2016 through 2020. Around the world Scientists are working hard to investigate the effect of biochar on soil, plants and the environment (Ahmed et al., 2018).

Bibliometrics is a statistical analysis of articles, books and any other publications (OCDE 2018 ), which makes it possible to measure quality and quantity of publications from institutions, individuals and countries. It also makes it possible to obtain information such as effective publication, authors, institutions, networks of citations among others (Demir, 2018). This type of approach differs from a review article, whose main objective is to discuss the latest advances, challenges and future directions for a given topic (Jauharah et al.,2018) However, a specific bibliometric analysis guiding the biochar and its adsorbent power, has not yet been realized, according to the research done by the authors. In this sense, this study aims to analyse qualitatively and quantitatively the publications of research articles, in the period 2011-2021, related to the use of biochar as an adsorbent of organic and inorganic contaminants and other substances, demonstrating research trends in the area and direct opportunities for new studies on the topic.

\section{Methodology}

Data used in this bibliometric analysis were collected in October 2020 in the Scopus database. This database indexes multidisciplinary scientific publications from around the world, being scientifically recognized for both the quantity and 
quality of indexed scientific journals. Woszezenk (2013) states that the search results showed that Scopus indexes a much larger number of works than the other databases.

After choosing the indexer, search criteria were established. In order to carry out a wide coverage of publications on the topic of the use of biochar as an adsorbent, the area as a whole was investigated, in order to collect all possible studies developed.

In the search field corresponding to "title", "keywords" and "abstract" the words: "BIOCHAR ADSORBENT" were inserted, refining for articles and excluding reviews, conference articles, book chapter etc. After the search, the articles were analysed based on the database search metrics with the aid of the VOsviewer ${ }^{\circledR}$ software. The data obtained were: number of publications over ten years (2011-2021), keywords, countries, distribution of publications in areas, themes and journals, and mapping of the authors. The results were presented by means of graphics and with the aid of mapping. The five most relevant works, based on the highest number of citations, will be explored in greater detail.

\section{Results and Discussion}

\section{Number of publications over the 10 years (2011-2021)}

1529 articles were selected between the years 2011-2021, based on the search criteria used. There was an increase in the number of publications over the years, indicate in figure 1. The articles went from 11 in 2011 to 418 in 2020 . In particular, the number of publications increased significantly from 2016 to 2020 (121 to 418). A 50\% increase in the number of studies referring to biochar in the years 1999-2018 was observed by Li et al. (2020). Kim et al. (2016) e Ahmed et al. (2018) also concluded that there is a growing worldwide trend in studies with biochar, this increase in research interest may be linked to the versatility of the material as an adsorbent.

Figure 1. Trend in the number of publications over the years (2011 -2021).

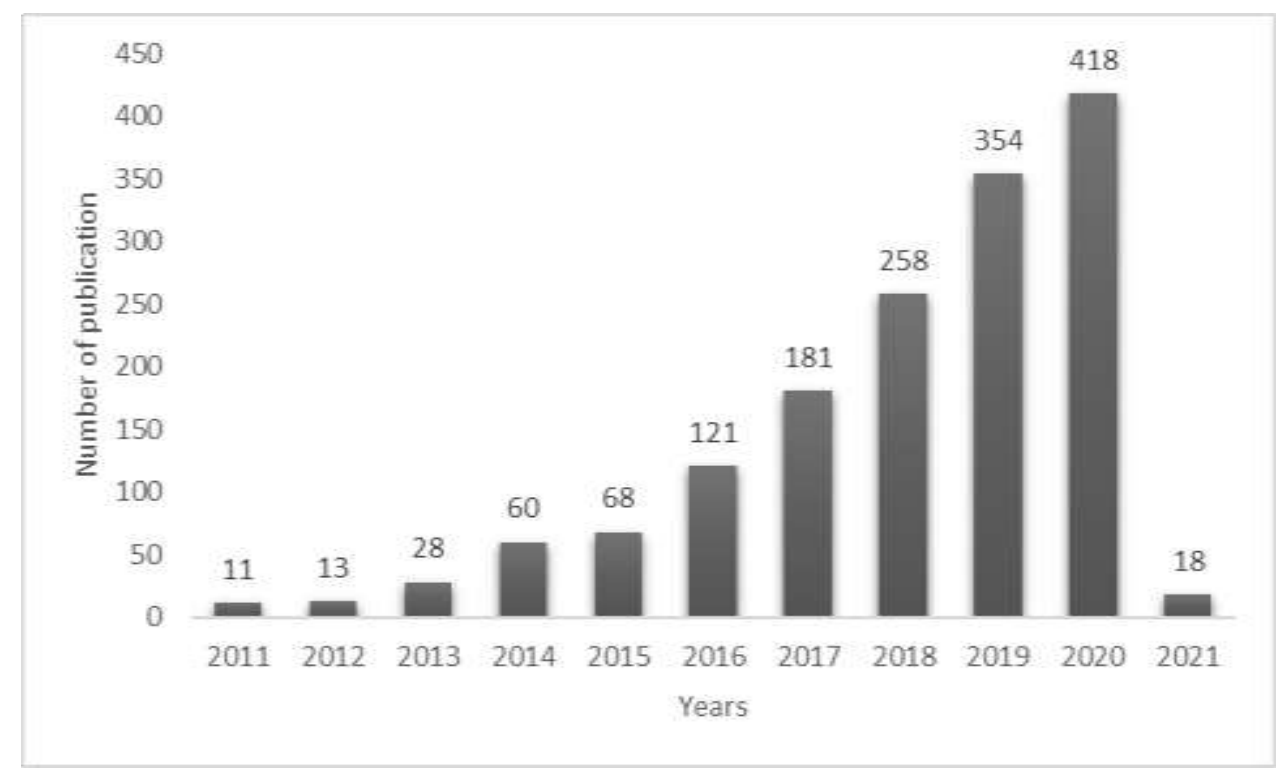

Source: Authors (2021).

It should be noted that one of the reasons for this behavior may be the profit of the companies that promote the uses of biochar, due to its similarity to the "Terra Preta de Indio". (Ernsting,2011). This economic interest may have promoted the 
financial contribution and implied an increase in the number of studies on the benefits of using biochar. For Abdeljaoued et al. (2020) the potential for future research on the topic of biochar may still be very high.

However, the risks inherent in the production, handling and end use of the biochar must be considered. The type of raw material used may contain pathogens with a risk potential and little is known about the effect of pyrolysis on the elimination of these organisms (Braomort,2010). Longer-term studies are needed to more accurately determine the consequences of biochar production and use.

\section{Distribution of articles based on citations, journals and areas}

Table 1 shows the twenty most cited articles, and the most cited article, with 514 citations, was published in 2011. The three most cited papers were published in the journal Bioresource Technology. It is an English journal covering the areas of Environmental Sciences, Energy and Chemical Engineering. Since 1991 he has had coverage at Scopus and is owned by Elsevier.

Table 1. List of the twenty most cited articles and year, number of citations and journals indexed in Scopus.

\begin{tabular}{|c|c|c|}
\hline Study Tittle & Year & No. of citations per journal \\
\hline $\begin{array}{l}\text { Adsorption of copper and zinc by biochars produced from pyrolysis of } \\
\text { hardwood and corn straw in aqueous solution }\end{array}$ & 2011 & $\begin{array}{l}514 \\
\text { Bioresource Technology }\end{array}$ \\
\hline $\begin{array}{l}\text { Preparation and characterization of a novel magnetic biochar for } \\
\text { arsenic removal }\end{array}$ & 2013 & $\begin{array}{c}327 \\
\text { Bioresource Technology }\end{array}$ \\
\hline $\begin{array}{l}\text { Biochar derived from anaerobically digested sugar beet tailings: } \\
\text { Characterization and phosphate removal potential }\end{array}$ & 2011 & $\begin{array}{l}326 \\
\text { Bioresource Technology }\end{array}$ \\
\hline $\begin{array}{l}\text { Hydrogen peroxide modification enhances the ability of biochar } \\
\text { (hydrochar) produced from hydrothermal carbonization of peanut hull } \\
\text { to remove aqueous heavy metals: Batch and column tests }\end{array}$ & 2012 & $\begin{array}{c}323 \\
\text { Chemical Engineering Journal }\end{array}$ \\
\hline $\begin{array}{l}\text { Removal of phosphate from aqueous solution by biochar derived from } \\
\text { anaerobically digested sugar beet tailings }\end{array}$ & 2011 & $\begin{array}{c}321 \\
\text { Journal of Hazardous Materials }\end{array}$ \\
\hline $\begin{array}{l}\text { Modeling and evaluation of chromium remediation from water using } \\
\text { low cost bio-char, a green adsorbent }\end{array}$ & 2012 & $\begin{array}{c}300 \\
\text { Journal of Hazardous Materials }\end{array}$ \\
\hline $\begin{array}{l}\text { Modification of bio-char derived derived from fast pyrolysis of } \\
\text { biomass and its application in removal of tetracycline from aqueous }\end{array}$ & 2012 & $\begin{array}{l}280 \\
\text { Bioresource Technology }\end{array}$ \\
\hline Synthesis of porous $\mathrm{MgO}$-biocha & 2012 & $\begin{array}{c}276 \\
\text { Chemical Engineering Journal }\end{array}$ \\
\hline Removal of arsenic by magnetic biochar & 2015 & $\begin{array}{c}265 \\
\text { Bioresource Technology }\end{array}$ \\
\hline Cadmium and lead remediation using magnetic oak wood & 2014 & $\begin{array}{c}259 \\
\text { Chemical Engineering Journal }\end{array}$ \\
\hline Removal of arsenic, methylene blue, and phosphate by biochar & 2013 & $\begin{array}{c}226 \\
\text { Chemical Engineering Journal }\end{array}$ \\
\hline $\begin{array}{l}\text { Batch adsorption of basic dye using acid treated kenaf fibre char: } \\
\text { Equilibrium, kinetic and thermodynamic studies }\end{array}$ & 2012 & $\begin{array}{c}221 \\
\text { Chemical Engineering Journal }\end{array}$ \\
\hline $\begin{array}{l}\text { Evaluation of slow pyrolyzed wood and rice husks biochar for } \\
\text { adsorption of ammonium nitrogen from piggery manure anaerobic } \\
\text { digestate slurry }\end{array}$ & 2015 & $\begin{array}{c}213 \\
\text { Science of the Total Environment }\end{array}$ \\
\hline $\begin{array}{l}\text { Adsorption of methyl violet from aqueous solutions by the biochars } \\
\text { derived from crop residues }\end{array}$ & 2011 & $\begin{array}{l}208 \\
\text { Bioresource Technology }\end{array}$ \\
\hline
\end{tabular}




\begin{tabular}{lcc}
\hline $\begin{array}{l}\text { Comparison of sorption and desorption studies of heavy metal ions } \\
\text { from biochar and commercial active carbon }\end{array}$ & 2017 & $\begin{array}{c}203 \\
\text { Chemical Engineering Journal }\end{array}$ \\
\hline $\begin{array}{l}\text { Sorption of bisphenol A, 17 } \alpha \text {-ethinyl estradiol and phenanthrene on } \\
\text { thermally and hydrothermally produced biochars }\end{array}$ & 2011 & $\begin{array}{c}203 \\
\text { Bioresource Technology }\end{array}$ \\
\hline $\begin{array}{l}\text { Removal of emerging contaminants from the environment by } \\
\text { adsorption }\end{array}$ & 2018 & $\begin{array}{c}202 \\
\text { Ecotoxicology and Environmental Safety }\end{array}$ \\
\hline $\begin{array}{l}\text { Biochar-supported zerovalent iron for removal of various contaminants } \\
\text { from aqueous solutions }\end{array}$ & 2014 & $\begin{array}{c}196 \\
\text { Bioresource Technology }\end{array}$ \\
\hline $\begin{array}{l}\text { Enhancing phosphate adsorption by Mg/Al layered double hydroxide } \\
\text { functionalized biochar with different } \mathrm{Mg} / \mathrm{Al} \text { ratios }\end{array}$ & 2016 & Science of the Total Environment \\
\hline
\end{tabular}

Source: Authors (2021).

CiteScore measures the average citations received per document published in the series within Scopus, is an index similar to JCR (Journal Citation Reports). Bioresource Technology's CiteScore is 12.8 in 2019 and JCR is 7.5 in same year. The second magazine that appears most among the list of twenty articles (table 1) is the Chemical Engineering Journal, a Swiss magazine, which had Scopus coverage in the years 1975 and 79 and then returned in 1996 until today. The Chemical Engineering Journal covers the areas of Chemical Engineering, Chemistry and Environmental Engineering. Its CiteScore is 15.2 and JCR 10.6 in 2019. Both magazines have a relevant impact factor.

In the list in Table 1, the years 2019, 2020 and 2021 did not appear, as the twenty most cited articles were selected, so these years (2019-2021) had citations less than 190.

In addition to the Bioresource Technology periodical being the most cited, it is also the one that publishes the most on the topic. The journal published 124 articles in the years observed, corresponding to $20 \%$ of the total publication of articles in Table 2.

Table 2. Periodicals and numbers of publications/year indexed in Scopus and main areas of study.

\begin{tabular}{|c|c|c|c|}
\hline Journal & Publications & Area of Study & Year \\
\hline Bioresource Technology & 124 & $\begin{array}{c}\text { Environmental } \\
\text { Science } \\
(37 \%)\end{array}$ & 2019 \\
\hline Science Of The Total Environment & 94 & $\begin{array}{c}\text { Chemical } \\
\text { Engineering }(15 \%)\end{array}$ & 2020 \\
\hline Chemosphere & 79 & $\begin{array}{l}\text { Chemistry } \\
(13,1 \%)\end{array}$ & 2020 \\
\hline Environmental Science And Pollution Research & 74 & $\begin{array}{l}\text { Other areas } \\
(34,9 \%)\end{array}$ & 2018 \\
\hline Chemical Engineering Journal & 50 & & 2019 \\
\hline Journal Of Environmental Management & 46 & & 2019 \\
\hline Journal Of Hazardous Materials & 42 & & 2020 \\
\hline Journal Of Cleaner Production & 40 & & 2018 \\
\hline Rsc Advances & 37 & & 2016 \\
\hline Water Air And Soil Pollution & 35 & & 2017 \\
\hline
\end{tabular}

Source: Authors (2021).

Its peak of publications was in the year 2019. For Li et al. (2020), Ahmed et al. (2018) and Jauharah et al (2018) Bioresource Technology is the most productive journal. It covers several topics related to biochar and not only related to 
adsorption and adsorbent. These results should encourage researchers to subscribe to the journal and even publish their results to increase the dissemination of their research (Ahmed et al.,2018).

161 different journals from different areas of knowledge were observed, among them, three are more relevant, Environmental Science, Chemical Engineering and Chemistry. Unlike the study of Ahmed et al.2018 where most of the articles were related to the area of agriculture, due to the authors' research having used the word "biochar", which ranges from production to applicability in agriculture. In this work, the area of adsorption is pollutants, or any other substance is directly linked to the environmental area and chemistry. The results obtained by Li et al (2020) and Kim et al.(2016) corroborate with the data found in the present study.

Among the most relevant areas for this research, other areas were also found: Energy and Fuels, Engineering, Agriculture, Material Sciences, Biotechnology and Microbiology, Science and Technology, Medicine and other topics. This proves that biochar is a multidisciplinary field of research.

\section{Authors' Statistics}

There have been 3979 authors who have contributed to studies related to adsorption with biochar in the past ten years. Among them, five stand out (Table 3) Li.Y is from the Biochar Engineering Research Center in Zhejiang Province, Hangzhou, has contributed most publications on the subject to date, with 70 documents, followed by Liu.Y. (58) published articles, Gao B. (43), Wang.Y (50) and Wang H (50) publications. Gao B, despite having contributed less than Wang Y, the author is in evidence due to the number of times cited (3673). Gao belongs to the Department of Geological Sciences, University of Florida-USA. Interestingly, these authors have networks that end up contributing to each other's work. Of these five authors mentioned above, only one is from the USA, the others are from China.

Table 3. Authors who produced the largest number of publications on biochar and its institutions indexed in Scopus.

\begin{tabular}{|c|c|c|c|}
\hline Author & Institution/Country & Number of publications & Citations \\
\hline Li Y & $\begin{array}{c}\text { Zhejiang Biochar Engineering Research } \\
\text { Center. China }\end{array}$ & 70 & 1291 \\
\hline Liu Y & $\begin{array}{l}\text { College of Environmental Science and } \\
\text { Engineering, Hunan University, } \\
\text { Changsha, China } \\
\text { Key Laboratory of Environmental } \\
\text { Biology and Pollution Control, Hunan } \\
\text { University,China }\end{array}$ & 58 & 1118 \\
\hline Gao B & $\begin{array}{c}\text { Department of Geological Sciences, } \\
\text { University of Florida-USA }\end{array}$ & 43 & 3673 \\
\hline Wang Y & $\begin{array}{c}\text { Agricultural Clear Watershed Group, } \\
\text { Instituto de Meio } \\
\text { Institute of Environment and } \\
\text { Sustainable Development in Agriculture, } \\
\text { Chinese Academy of Agricultural } \\
\text { Sciences, China }\end{array}$ & 50 & 935 \\
\hline Wang $\mathrm{H}$ & $\begin{array}{c}\text { Department of Agricultural and } \\
\text { Biological Engineering, University of } \\
\text { Florida,USA }\end{array}$ & 50 & 935 \\
\hline
\end{tabular}

Source: Authors (2021).

These authors' affiliations show that biochar research works in the areas of environmental engineering, environmental biology, geology and agriculture. In addition, two of the authors belong to the University of Florida, which is considered one of the most productive institutions (Abdeljaoued et al., 2020). 


\section{Countries}

88 countries were found studying on the topic. Among these, China stands out, as so far it has contributed 837 works, followed by the USA (213), India (139) and South Korea (116) (Figure 2). It is clear that China and the USA have a significant impact in this field of research (Li.D, et al., 2020.Kim et al., 2016). Brazil published 41 papers in the area.

Figure 2. Number of publications and countries.

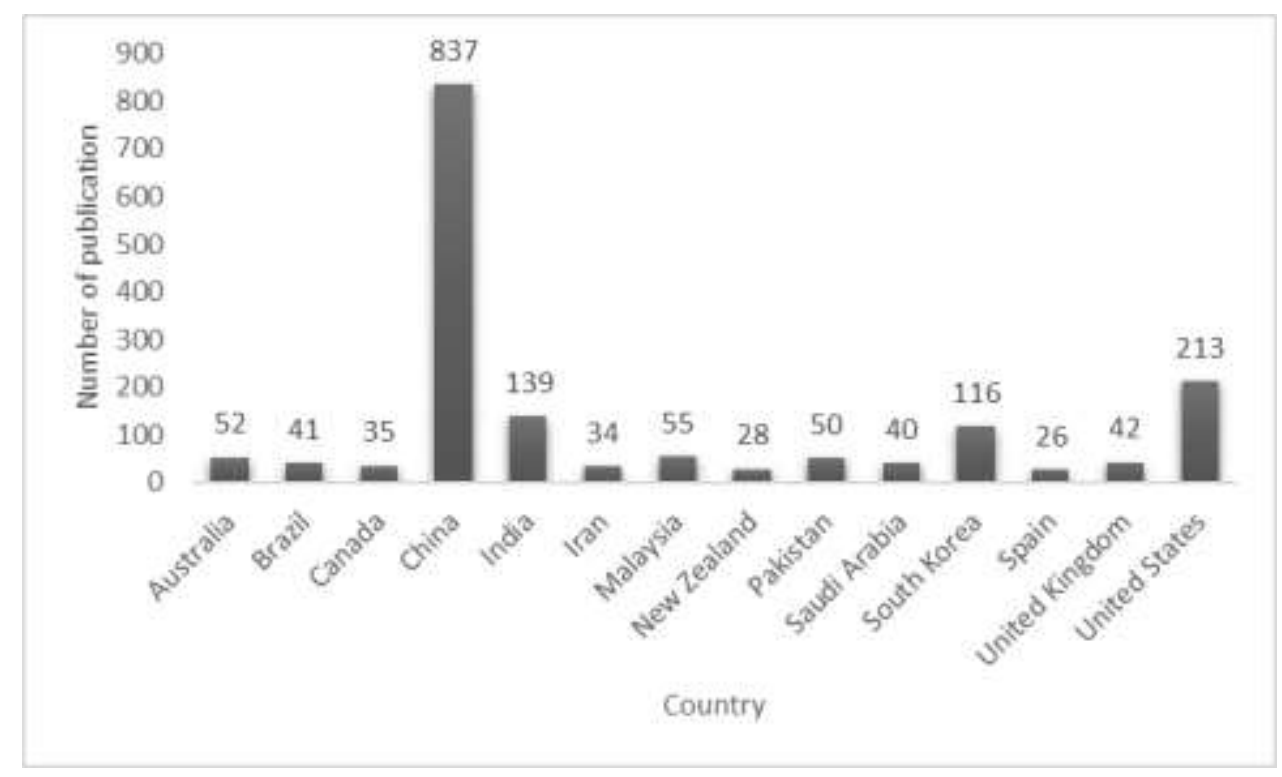

Source: Authors (2021).

This difference between China and the other countries, including Brazil, is linked to the incentive to research and development in the country. The two largest world markets that lead investment in research and development are the USA (US \$ 500 billion / year) and China (US \$ 408 billion / year), these two countries represent $62 \%$ of the global investment in the area. Brazil is in ninth place, investing (US \$ 42.1 billion), this represents $2.3 \%$ of the world investment in research and development. Brazil is still ahead of countries like Holland, Russia, Italy and Canada (Revista Negócios, 2019,UFRGS, 2018).

In relation to publications, a study was presented in 2018 by the National Science Foundation (NSF) of the United States that pointed out that China produces more scientific articles in the world. Brazil was in 12th place among the countries with the largest number of published articles, with 53 thousand articles in 2016, while China, in the same year, published 426 thousand papers (UFRGS, 2018).

Brazil has seen an increase in its publications, this may have been due to graduate programs. According to the Ministry of Education (MEC c2018), Brazil has 122,295 graduate students spread across 9296 graduate programs (SUCUPIRA, 2016). The country needs more financial incentives in education, research and technology to develop studies in all areas of knowledge.

Tangled lines in figure 3 show the partnerships made in works on adsorption with biochar. China stands out for researching together with several countries like New Zealand, Pakistan, Australia and Malaysia. Brazil has working partnerships with Italy, Spain, Germany, Qatar, Pakistan and Vietnam. The language of the articles is predominantly English followed by Chinese. The Portuguese language appeared only in one article of the search. 
Research, Society and Development, v. 10, n. 10, e61101018520, 2021

(CC BY 4.0) | ISSN 2525-3409 | DOI: http://dx.doi.org/10.33448/rsd-v10i10.18520

Figure 3. Interrelation of countries that research together on Biochar indexed in Scopus.

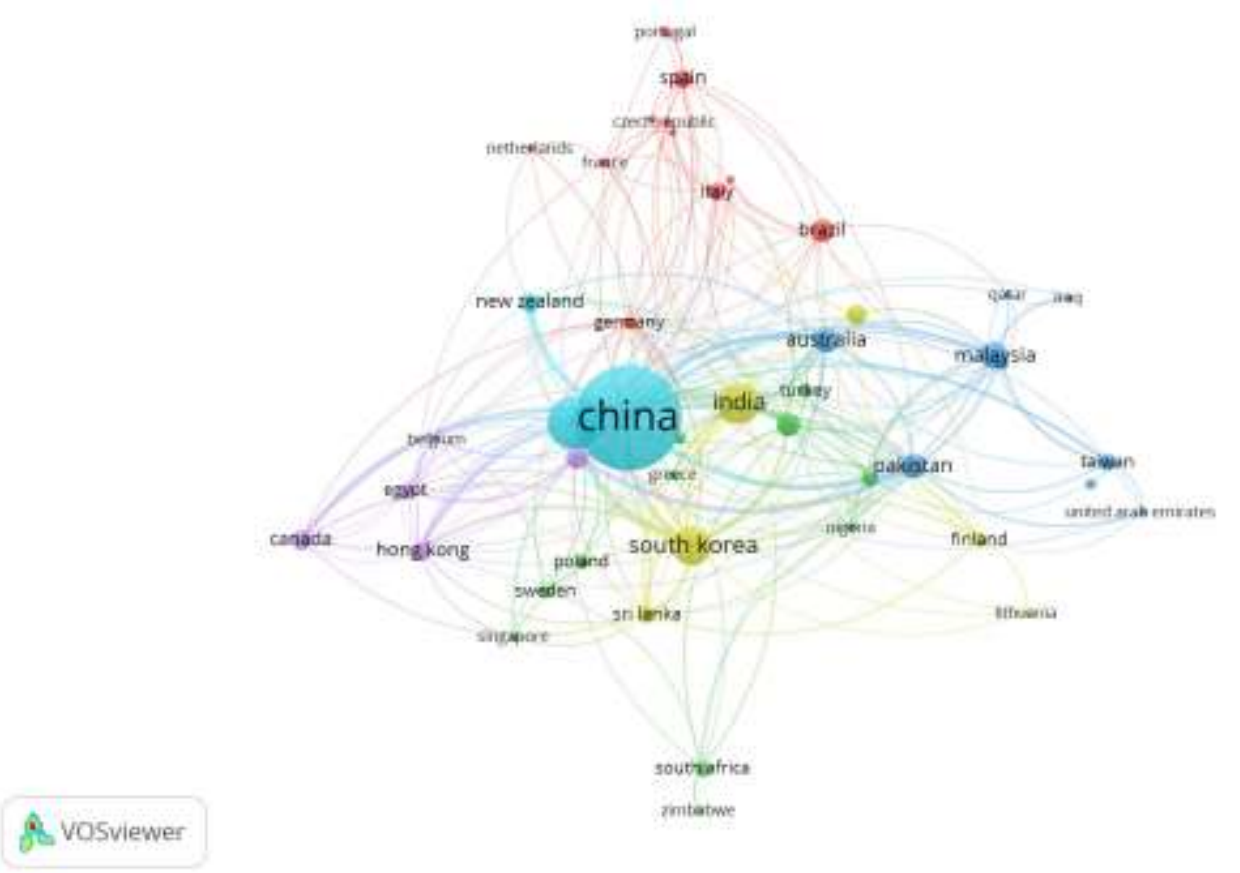

Source: Authors (2021).

\section{Keywords}

2895 authors' keywords were registered, of which 185 reached the limit of 5 minimum occurrences for mapping in VOSviewer. Results showed "Biochar" was the keyword with the most frequency, 729 and 1483 links to other keywords, in Figure 4, followed by the word "Adsorption" with a frequency of 586 and 1283 links to other keywords.

Figure 4. Vosviewer mapping author keywords.

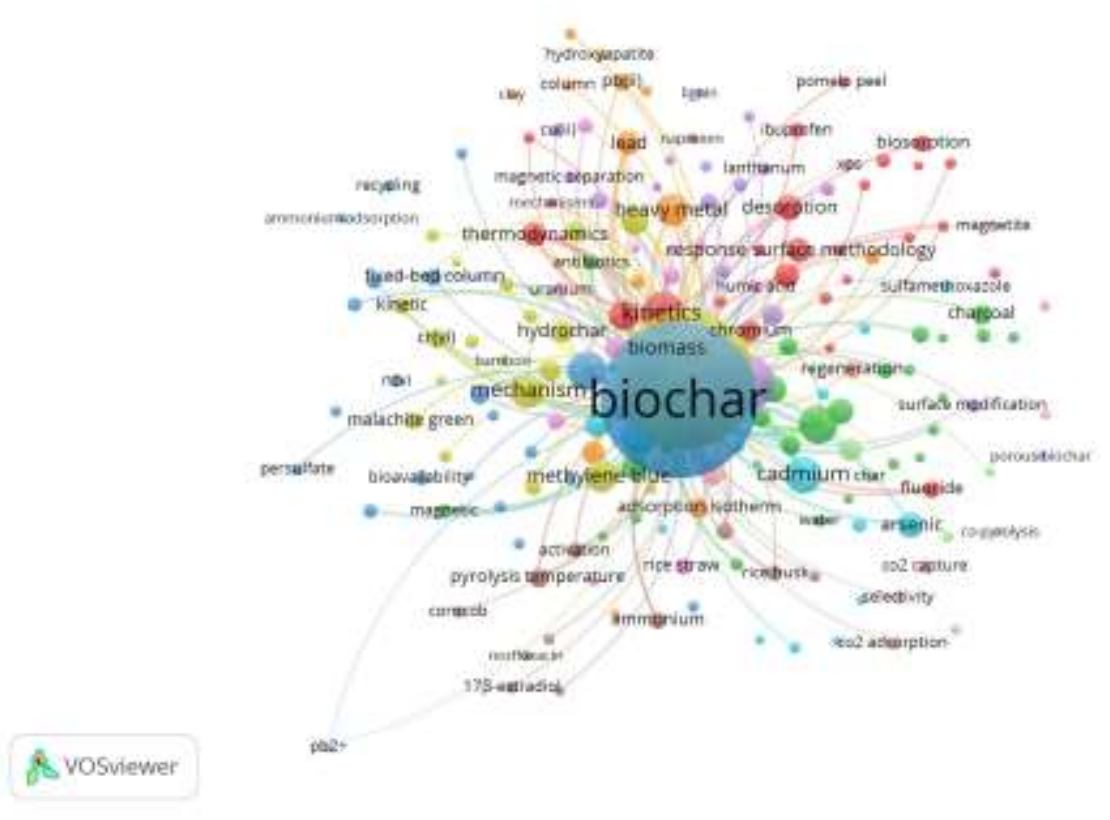

Source: Authors (2021). 
In the mapping there was an overlap of the words biochar and adsorption, due to the large number of articles that use them in their keywords. Other terms such as "pyrolysis," Kinetcs "," Cadmium "," heavy-metal "," sorption "," mechanism "," ishoterms "," desorption " were also found. With the keywords, it can be observed that the ten most cited terms are linked to articles that contemplate the themes of burning, kinetics, adsorption, isotherms and desorption of biochar, evidencing in the works adsorption by biochares and the importance of the theme in research.

Through the keywords it is possible to trace the direction of the research. Li et al (2019), noted that the behavior of research over the years 1999 through 2018 has changed. In the years 1999 to 2010, the key words that appeared the most were bio-char, black carbon, charcoal, biogas, bio-oil, which reflected an initial stage of knowledge. In the second stage from 2011 to 2015, the keywords slow pyrolysis, fast pyrolysis, raw material, lignin, etc. Preparation, application of biochar for soil remediation and reduction of greenhouse gases, demonstrating an increase in knowledge and it is in this phase that this study fits, because the most relevant articles, listed in Figure 1, are from the years 2011- 2013 and are associated with the topic of remediation and sorption.

In third phase, authors report that from 2015 to 2018 the focus is on a new field of application of biochar, for aerobic digestion and microwave-based pyrolysis ( $\mathrm{Li}$ et al.,2019). From 2008 to 2018 there was a desire for research with main focuses on accumulation, remediation and repair of trace elements in the soil (Wu.Y et al.,2020).

Exploring the five relevant articles (2011-2021)

Following the list of the 20 most cited articles above (Table 1), this topic will analyse the five most relevant articles taking into account the number of citations.

All five articles have partnerships between China and the USA. Three of them were published in Bioresource Technology magazine, one in Hazardous Materials and the other in Chemical Engineer Journal. They cover several areas of knowledge, from soil sciences to microbiology and toxicology, agricultural engineering, geological sciences and civil engineering.

In the articles, authors made a generic introduction commenting on biochar potentials. And all made chemical and physical characterizations of the materials. Table 4 shows the titles of articles in order of relevance, year of publication, objectives and conclusions of the authors. 
Table 4. Title, year of publication, objectives and conclusions of the five most relevant articles indexed in Scopus.

\begin{tabular}{|c|c|c|c|}
\hline Title & Year & Objectives & Conclusions \\
\hline $\begin{array}{c}\text { Adsorption of copper and zinc by } \\
\text { biochars produced from pyrolysis } \\
\text { of hardwood and corn straw in } \\
\text { aqueous solution }\end{array}$ & 2011 & $\begin{array}{l}\text { Investigate mechanisms and } \\
\text { sorption capacity of } \mathrm{Cu} \text { and } \mathrm{Zn} \\
\text { by two biochares derived from } \\
\text { hardwood and corn straw in } \\
\text { aqueous solution. }\end{array}$ & $\begin{array}{l}\text { The efficiency in the adsorption of } \\
\text { metals by biochares decreased } \\
\text { although the total removal increased } \\
\text { with increasing doses. Cu competed } \\
\text { with } \mathrm{Zn} \text { when the concentration was } \\
\text { greater than } 1 \mathrm{nM}\end{array}$ \\
\hline $\begin{array}{l}\text { Preparation and characterization } \\
\text { of a novel magnetic biochar for } \\
\text { arsenic removal }\end{array}$ & 2013 & $\begin{array}{c}\text { Evaluate the efficiency of } \\
\text { cotton wood biochar with } \\
\mathrm{Fe} 2 \mathrm{O} 3 \text { for removal of As }(\mathrm{V}) \text { in } \\
\text { aqueous medium }\end{array}$ & $\begin{array}{l}\text { This material is an excellent } \\
\text { adsorbent }\end{array}$ \\
\hline $\begin{array}{l}\text { Biochar derived from } \\
\text { anaerobically digested sugar beet } \\
\text { tailings: Characterization and } \\
\text { phosphate removal potential }\end{array}$ & 2011 & $\begin{array}{l}\text { Determine whether } \\
\text { anaerobically digested beet } \\
\text { tailings can be effective in } \\
\text { producing biochar. Evaluate the } \\
\text { physicochemical properties and } \\
\text { observe the phosphate removal } \\
\text { capacity. }\end{array}$ & $\begin{array}{l}\text { Anaerobic digestion increases } \\
\text { phosphate adsorption capacity } \\
\text { compared to undigested biochar. }\end{array}$ \\
\hline $\begin{array}{l}\text { Hydrogen peroxide modification } \\
\text { enhances the ability of biochar } \\
\text { (hydrochar) produced from } \\
\text { hydrothermal carbonization of } \\
\text { peanut hull to remove aqueous } \\
\text { heavy metals: Batch and column } \\
\text { tests }\end{array}$ & 2012 & $\begin{array}{l}\text { The modification of hydrogen } \\
\text { peroxide to increase the } \\
\text { capacity of the biochar } \\
\text { produced from the } \\
\text { hydrothermal carbonization of } \\
\text { peanut shells to remove heavy } \\
\text { metals in aqueous solutions }\end{array}$ & $\begin{array}{l}\text { The increase in oxygen from peroxide } \\
\text { increases the adsorption of metals. }\end{array}$ \\
\hline $\begin{array}{l}\text { Removal of phosphate from } \\
\text { aqueous solution by biochar } \\
\text { derived from anaerobically } \\
\text { digested sugar beet tailings }\end{array}$ & 2011 & $\begin{array}{l}\text { Identify the mechanisms that } \\
\text { govern phosphate adsorption in } \\
\text { beet biochar and measure the } \\
\text { kinetics and equilibrium } \\
\text { isotherms of phosphate } \\
\text { adsorption. }\end{array}$ & $\begin{array}{l}\text { Phosphate removal was controlled } \\
\text { mainly by adsorption in colloidal and } \\
\text { nanometric particles of } \mathrm{MgO} \text { on the } \\
\text { biochar surface. }\end{array}$ \\
\hline
\end{tabular}

Source: Authors (2021).

First article is a highly relevant study in the area by the number of citations. He worked with $\mathrm{Cu}$ and $\mathrm{Zn}$ sorption by biochar and showed their efficiencies. In the second work, what drew attention was the use of magnetic biochar, which according to the authors, after removing Arsenic, the material can be separated. The authors concluded the material is an excellent adsorbent.

The third study used anaerobically digested beet tailings to produce the biochar. In the fourth article, the authors worked with the modification of hydrogen peroxide to increase the capacity of the biochar produced from the hydrothermal carbonization of peanut shells, to remove heavy metals in aqueous solutions. And the hydrogen peroxide oxygen increased the adsorption of metals. The fifth study observed, has the same theme already addressed in study cited number three, which worked with the removal of phosphate in aqueous solution with the same biochar derived from anaerobically digested beet tailings. In the previous article, authors characterized the biochar and tested its removal capacity and identified the mechanisms that govern phosphate adsorption in beet biochar and measured the kinetics and equilibrium isotherms of phosphate adsorption, thus complementing the study previously published. Authors concluded that there is a superior ability to remove phosphate from water under a $\mathrm{pH}$ range and competitive ion conditions. Batch sorption experiments and post-sorption characterizations suggested that phosphate removal was controlled mainly by adsorption on colloidal and nanometric particles of $\mathrm{MgO}$ on the biochar surface. 
Sometimes the works are limited to only characterize the materials, due to the variety of options to produce different types of biochar and because applications and functions of biochar are highly dependent on the physicochemical properties (Cao and Harris,2010). In this research area, the feeling that it gives is of no evolution as in other areas of study with biochar. For example, research is already well defined and based on burning. It is something that has already been studied and solved a lot, however this does not happen with the adsorptive power of the materials, due to the heterogeneity of the raw materials and the variables involved such as $\mathrm{pH}$, temperature, doses, particle size, ASE, which type of organic adsorbate, inorganic, etc. This fact leads us to another question. Studies of biochar preparation by different methods of the same raw material, followed by adsorption with the same adsorbents are rare. Likewise, identical biochar preparations of the same material, followed by adsorption studies of the same biochares, are necessary to assess reproducibility (Dinesh et al.,2019). The scientific work is done in a laboratory, there are no studies on a large scale. Among the studies analysed, there are no studies with soils and plants and applicability. They are limited to water and solutions, but it is also not applied in treatment plants, for example. It is known that biochar can be produced at low cost, but it does not have economic studies of production and feasibility for application.

\section{Recommendations for future research}

Based on this bibliometric analysis, the following is recommended for future research:

a) Economic studies of biochar production in biorefineries and companies in the industry for possible commercialization and implantation;

b) How could large-scale production improve soil quality in areas that are not productive for agriculture/contaminated and improve water quality? Assessing cost benefit

c) Have a standard of methodology and material for the use of adsorption and remediation. As a production control to obtain the desired chemical and physical properties for adsorption. Some features will serve for small uses, while others will have high applicability. Detailed knowledge is needed to compare with other adsorbents. More understanding of the aspects of adsorption of biochar is needed, as the various types of adsorbates (organic and inorganic) are distributed along biochares at all levels (pores, internal surfaces and below pores, in all solid material).

d) Pollutant / contaminant removal needs to be studied more broadly, aiming not only at adsorptive capacity but also at recycling and disposal of material.

\section{Conclusion}

- Publications related to adsorption are growing in the last ten years.

- Bioresource Technology magazine stood out in the area.

- China has published most of the studies and especially the majority of authors are Chinese, also suggesting China's focus on this field. China and the USA are the most active countries in publications.

- Li.Y, Gao, B, Wang Y, Wang H were the main authors in this field of research and played a role in promoting the development and expansion of the field.

- The keywords most used by the authors were biochar and adsorption.

- The fields of study are diverse, but the strongest area in the subject is environmental sciences.

- In the future, long-term field experiments must be established to deepen the adsorption mechanisms. These studies will provide the theoretical basis for the promotion and large-scale application of biochar generating sustainable development of the environment. 


\section{Acknowledgments}

Thanks to CAPES and UDESC for their support in the research.

\section{References}

Abdeljaoued, E., Brulé, M., \& Tayibi, S. (2020). Bibliometric analysis of the evolution of research trends and scientific production of biochar. Clean .Techn Environ Policy.Review. 22, 1967-1997.

Ahmed, S.F., Ahmed, S., Vanga \& Vijaya, R. (2018). Global Bibliometric Analysis of the Research in Biochar. Journal of Agricultural \& Food Information, 19(3), 228-236. 10.1080/ 10496505.2017.1403328.

Ajmal, Z., Muhmood, A., Dong, R., \& Wu, S. (2020).Probing the efficiency of biochar derived from magnetically modified biomass for effective removal of phosphate .Journal Environ. Manag. 253. 10.1016.2019.109730.

Albuquerque, J. A, Salazar, P; Barron. V., Torrent, J., Villar. R. (2013). Reserch. Increased wheat production by biochar under different levels of fertilization minral. Agron Sustain . 33,475-484.

Arfaoui, A., Ibrahimi, K. \& Trabelsi, F. (2019).Research. Biochar application to soil in arid conditions: a bibliometric study of research status and trends. Arab Journal Geosci 12, 45. 10.1007/s12517-018-4166-2.

Bracmort, K. (2010). Biochar: examination of an emerging concept to mitigate climate change, s. 1.: Congressional Research Service Report.

Cao, X.; Harris, W.(2010). Properties of dairy-manure-derived biochar pertinent to its potential use in remediation. Research Bioresour. Technol. 101,52225228.

Chen, Y., Yuan, H., Lu, T., Wang, Y., \& Huang, H. .(2014). Influence of pyrolysis temperature and waiting time on the properties of biochar derived from medicinal herb waste (Radix isatidis) and its effect on CO 2 emission in the soil.Journal of Analytical and pirolisis. 110 ,277 - 284. 10.1016.2014.09.016 .

Demir E, \& Comba A. (2018). The evolution of celiac disease publications: a holistic approach with bibliometric analysis. Irish Journal Medical Science.189,267-267.

Dinesh, M., Anku, S., Yong, S., Sik, O. k., Charles, U., Pittman, E. \& Yildirim, E. D. (2019).Research.Comparative bibliometric analysis of fertility preservation Annals. Med Res.26, 1622-1628.

Ernsting, A. Biochar - a climate smart solution? (2011).Report. Aachen Misereor. 1, 1-24.

Jauharah, M., Khudzari, D., Kurian, J., \& Tartakovsky, B. G.S., Raghavan,V.(2018). Bibliometric analysis of global research trends on microbial fuel cells using Scopus database,Biochemical Engineering Journal. 136, 51-60.

Junior, N. C. (2017). Influence of pyrolysis conditions on the adsorption capacity of $\mathrm{Pb}$ (II) ions by the biochar obtained from pine nuts (Araucaria angustifolia). Master's dissertation in Cheemisty Engeenier. UFSC.Retrieved from: https://repositorio.ufsc.br/xmlui/handle/123456789/178961 .

Kavitha, B., Reddy, P. V. L., Kim, B., Lee, S. S. Pandey, S. K, \& Kim, K. H. (2018). Review.Benefits and limitations of the biochar amendment in agricultural soils: a review. Journal Environ Manag 227,146-154. 10.1016.2018.08.082.

Kim, Y.S., Kim, C., \& Hyun, S.(2016). Biochar research trends and perspectives in South Korea based on bibliometric analysis. Journal of Korea Society waste management. 33 (3), $207-223.10 .9786 .2016 .33 .3 .207$.

Lehmann, J., \& Joseph, S (EDS).(2009). Biochar for environmental management: science and technology, Earthscan.

Lehmann, J. (2007). Bionergy on Black. Front Ecololy Environ 5, 381-387.

Li, D., Zhao, R., \& Peng, X. et al L. (2020)..Biochar-related Studies de 1999 a 2018:a bibliometric review. Environ Sci Pollut Res 27, 28982908. 10.1007/s11356-019-06870-9.

Liu, H., Guoren, X. U., \& Guibai, L. I. (2020).The characteristics of pharmaceutical sludge-derived biochar and its application for the adsorption of tetracycline,Science of The Total Environment.747. 10.1016/.2020.141492.

MEC.(2020). . Ministry of Education Portal Retrivied 20/08/2020 from http://portal.mec.gov.br/.

OCDE (2018). Glossary of statistical terms. Retrivied 15/9/2020 from https://stats-oecd-org.ez74.periodicos.capes.gov.br/glossary/search.asp.

O'connor, D. Peng, T. Y, Zhang, J. L., Tsang, D. C. W, Aless, I. D. S., Shen, Z. T., Bolan, N. S., \& Hou, D. Y. (2018)..Biochar application for the remediation of soils polluted by heavy metals: a review of field tests in situ. Sci Total Environ .619,815-826.

Saletnik, B., Zagula, G., Bajcar, M., Tarapatskyy, M., Bobula, G., \& Puchalski, C. (2019).Organic and inorganic contaminants removal from water with biochar, a renewable, low cost and sustainable adsorbent - A critical Biochar as a multifunctional component of the environment - a review. Appl Sci. 9 (6), 1139. 10.33909061139.

SucupiraPlatform:(2020). www.sucupira.capes.gov.br/sucupira/public/consultas/coleta/programa/quantitativos/quantitativoRegiao.xhtml;jsessi onid=SHTc osjP 9M yrOYuFJjhA nPk3.sucupira-215. 
Research, Society and Development, v. 10, n. 10, e61101018520, 2021

(CC BY 4.0) | ISSN 2525-3409 | DOI: http://dx.doi.org/10.33448/rsd-v10i10.18520

UFRGS- Federal University of Rio Grande do Sul. (2020). https://ufrgs.br/blogdabc/china-e-o-pais-que-produz-mais-artigoscientificos-no-mundo-brasil-e-o$12 \mathrm{o} /$

Wang, M., Zhu, Y., Cheng, L., Andserson, B., Zhao, X., \& Wang, D., Ding, (2018). A. Review on the use of biochar for soil contaminated with metal and sediment remediation. Journal Environ Sci 63,156-173.10.1016 / j.jes.2017.08.004.

Wang, L., Wang, Y., M. A, F., Tankpa, A., Bai, S., Guo, X., et al.(2019). Mechanisms and reuse of modified biochar used to remove heavy metals from wastewater: a review. Environmental Science.668,1298-1309. 10.1016/j.scitotenv.2019.03.011.

Woszezenki, C. R., \& Goncalves, A. L.(2013). Biomedical text mining: a bibliometrics review. Perspect. ciênc. inf., 18 (3), 24-44.

Wu, Y., H. \& Jin, S. F. (2020). Bibliometric analysis of soil repair contaminated by heavy metals based on CiteSpace. Journal of Agro-Environment Science. $39,3,454-461$.

Yuan, Y., Bolan, N., Prãcvoteau, A., Vithanage, M., Kumar Biswas, Sik Ok, Y., \& Wang, H. (2017). Applications of biochar in redox-mediated reactions. Bioresource Technology, 246, 271-281. 10.1016/j.biortech.2017.06.154.

Hassan, M., Yanju, L., Ravi, N., Sanjai, J., Jianhua, D. U., Fangjie, Q. I., \& Ian, R. W. (2020).Influences of feedstock sources and pyrolysis temperature on the properties of biochar and functionality as adsorbents: A meta-analysis,Science of The Total Environment.744 . 10.1016/j.scitotenv.2020.140714. 